\title{
Distribusi dan Luas Stomata pada Enam Jenis Tanaman Dikotil
}

\section{(Distribution and Area of Stomata on Six Types of Dicot Plants)}

\author{
Rini Primawati, Entin Daningsih* \\ (Diterima Desember 2020/Disetujui Desember 2021)
}

\begin{abstract}
ABSTRAK
Distribusi dan luas stomata berkaitan dengan laju transpirasi. Penelitian ini mengukur distribusi dan luas stomata pada tanaman dikotil yang digunakan sebagai tanaman hias. Penelitian menggunakan desain Rancangan Acak Lengkap (RAL) faktorial dengan faktor utama adalah enam jenis tanaman dikotil dan tiga bagian daun (atas, tengah, dan bawah). Faktor kombinasi adalah interaksi jenis dan bagian tanaman. Penelitian menggunakan lima ulangan dengan parameter yang diukur adalah distribusi dan luas stomata menggunakan metode replika dan mikrometer. Data dianalisis menggunakansistem analisis statistik model RAL faktorial dan dilanjutkan dengan uji beda nyata terkecil apabila perlakuan menghasilkan perbedaan nyata. Koefisien korelasi antara distribusi dan luas stomata dihitung untuk melihat hubungan keduanya. Jenis dan bagian tanaman berpengaruh nyata pada distribusi stomata sedangkan luas stomata dipengaruhi oleh faktor utama maupun faktor kombinasi. Syzygium paniculatum Gaertn memiliki distribusi stomata tertinggi dan berbeda dari jenis tanaman lainnya. Sementara itu, daun bagian bawah mempunyai distribusi stomata terendah dan berbeda dengan bagian tengah dan atas. Luas stomata Aerva sanguinolenta BI menunjukkan luas stomata tertinggi $(591,05)$ dibandingkan dengan jenis tanaman lainnya. Luas stomata pada daun bagian atas tanaman $(272,71)$ lebih rendah secara nyata dibandingkan bagian tengah dan bawah. Kombinasi antara jenis dan bagian bawah tanaman memperlihatkan luas stomata yang tertinggi dibandingkan kombinasi lainnya. Distribusi stomata berbanding terbalik dengan luas stomata pada tabaman dikotil.
\end{abstract}

Kata kunci: bagian tanaman, dikotil, distribusi stomata, luas stomata

\section{ABSTRACT}

Stomatal distribution and area are related to transpiration rate. This study measured stomatal distribution and area in dicotyledon plants used as ornamental plants. The study used Factorial Completely Randomized Design (CRD) with the main factors were six types of dicotyledon plants and three plant parts (top, middle and bottom). Combination factors were the interaction of plant species and parts. By using the replica method and micrometer, the study used five replications with the measured parameters: the stomatal distribution and area. Data were analyzed using SAS with the Factorial RAL model and continued with the LSD test if the treatments were significant. Correlation coefficients between stomatal distribution and area were calculated to see the relationship between the two. The types and plant parts significantly affected the stomatal distribution, while the stomatal area was influenced by the main and combination factors. Syzygium paniculatum Gaertn had the highest stomatal distribution and was different from other plant types. Meanwhile, lower leaves had the lowest stomatal distribution and differed from the middle and upper. Aerva sanguinolenta BI had the highest stomatal area (591.05) compared to other plant species. The stomatal area on the plant's upper leaves $(272,71)$ was significantly lower than the middle and lower parts. The combination between species and the lower part of the plant produced the highest stomatal area compared to other combinations. Stomatal distribution was inversely proportional to the stomatal area.

Keywords: dicotyledon, part of plant, stomatal area, stomatal distribution

\section{PENDAHULUAN}

Daun merupakan bagian tumbuhan yang tipis, lebar, kaya akan zat warna hijau yang dinamakan klorofil. Daun merupakan salah satu organ tumbuhan yang berasal dari batang yang berfungsi sebagai penangkap energi cahaya matahari melalui fotosintesis. Proses penangkapan energi cahaya matahari pada tumbuhan

Program Studi Pendidikan Biologi, Jurusan Pendidikan Matematika dan IImu Pengetahuan Alam, Fakultas Keguruan dan IImu Pendidikan, Universitas Tanjungpura, Jl. Profesor Dokter H. Hadari Nawawi, Bansir Laut, Pontianak 78115

* Penulis Korespondensi:

Email: entindaningsih@fkip.untan.ac.id menggunakan pori-pori yang berada di daun disebut dengan stomata.

Stomata merupakan celah dalam epidermis yang dibatasi oleh dua sel epidermis khusus, yaitu sel penutup (Izza \& Lily 2015) da adalah bagian utama tanaman yang berperan penting dalam penggunaan air. Selain itu, stomata berfungsi untuk perubahan yang sesuai dengan kondisi lingkungan untuk dapat meningkatkan kinerjanya (Lawson \& Blatt 2014), mempertukarkan gas $\mathrm{O}_{2}, \mathrm{CO}_{2}$, dan uap air dari lingkungan ke dalam daun dan sebaliknya (Nugroho et al. 2010). Celah dalam epidermis ini erat kaitannya dengan aktivitas transpirasi. Letak antara satu stomata dengan stomata lainnya dapat memengaruhi intensitas penguapan dari tumbuhan. Pengendalian kehilangan 
air sangat penting guna menghindari kehilangan air berlebihan pada daun (Setiawati \& Syamsi 2019). Karateristik stomata pada daun meliputi jumlah, kerapatan, dan jenis stomata. Jarak stomata yang terlalu berdekatan akan menghambat penguapan (Izza \& Lily 2015).

Proses transpirasi pada tumbuhan dapat dipengaruhi oleh faktor internal dari tumbuhan tersebut seperti distribusi stomata dan luas stomata. Distribusi stomata adalah kerapatan jumlah stomata pada sel epidermis dalam satu bidang pandang. Kerapatan jumlah stomata yang rendah dan sel epidermis yang tinggi pada satu bidang pandang menghasilkan distribusi stomata yang rendah, begitu juga sebaliknya (Hakim et al. 2013). Distribusi stomata berdasarkan rumus Meidner \& Mainsfield (dalam Nurten 2014) dihitung dengan mengukur jumlah stomata per unit area dan jumlah sel epidermis per unit area. Distrbusi stomata berkaitan dengan luas stomata; luas yang lebar mengakibatkan distribusi rendah.

Luas stomata adalah ukuran yang diukur melalui sel penjaga stomata untuk menentukan panjang dan luas stomata (Rohman \& Hamida 2017). Semakin lebar sel penutup membuka, semakin luas stomata membesar dan semakin tinggi transpirasi (Dewi et al. 2015). Luas stomata diukur menggunakan rumus Eberly (2016) berdasarkan jari-jari panjang dan jari-jari lebar stomata.

Penelitian ini mengukur distribusi stomata dan luas stomata pada enam jenis tanaman dikotil, yaitu puring (Codiaeum variegatum (L.) A. Juss.), sambang darah (Excoecaria cochinchinensis Lour), erpah (Aerva sanguinolenta BI.), rombusa putih (Tabernaemontana divaricata (L.) R. Br. ex Roem. \& Schult.,), pucuk merah (Syzygium paniculatum Gaertn.), dan bunga kertas (Bougainvillea glabra Choisy). Hasil pengukuran dari setiap tanaman dihubungkan untuk mengevaluasi seberapa kuat korelasi antara distribusi stomata dan luasnya.

Pada penelitian sebelumnya, Hastika dan Sunarseh (2018) mengukur luas dan jumlah stomata pada enam jenis tanaman dikotil yang sama. Ditemukan bahwa luas dan jumlah stomata keenam jenis tanaman tersebut beragam berdasarkan umur dan bagian daun pada setiap tanaman tetapi belum melakukan hubungan antara luas dan jumlah stomata. Oleh sebab itu, penelitian kali ini akan menghubungkan antara distiribusi dan luas stomata. Hubungan antara distribusi dan luas stomata diperlukan guna mengevaluasi perbandingan antara distribusi dan luas stomata pada satu bindang area pandang keenam jenis tanaman dikotil yang sama.

\section{METODE PENELITIAN}

\section{Bahan dan Alat}

Eksperimen di Labolatorium Biologi FKIP, Universitas Tanjungpura ini adalah untuk mengevaluasi pengaruh jenis, bagian tanaman, dan kombinasi jenis dan bagian tanaman. Rancangan penelitian adalah
RAL faktorial dengan memperhatikan dua faktor, yaitu faktor utama jenis tanaman dan bagian tanaman, dan faktor kombinasi jenis dan bagian tanaman. Dari keenam jenis tanaman dikotil digunakan tiga bagian daun, yaitu bagian atas, tengah, dan bawah dari satu cabang terbawah yang sama dengan lima ulangan masing-masing. Alat utama yang digunakan ialah mikroskop, mikrometer okuler, mikrometer objekif, handcounter, dan kamera telepon genggam. Bahan yang digunakan replika stomata dari enam jenis tanaman dikotil: puring (Codiaeum variegatum (L.) A. Juss.), sambang darah (Excoecaria cochinchinensis Lour), erpah (Aerva sanguinolenta $\mathrm{BI}$.), rombusa putih (Tabernaemontana divaricata (L.) R. Br. ex Roem. \& Schult.), pucuk merah (Syzygium paniculatum Gaertn.), dan bunga kertas (Bougainvillea glabra Choisy.

Metode pengukuran distribusi stomata mengacu kepada Meidner \& Mainsfield (dalam Nurten, 2014) dengan mengukur jumlah stomata per unit area dan jumlah sel epidermis per unit area dengan rumus:

$$
\mathrm{SI}=\frac{\text { Jumlah sel stomata perunit area }}{\text { Jumlah stomata perunit area }+ \text { jumlah sel epidermis perunit area }} \times 100 \%
$$

\section{Keterangan:}

$\mathrm{SI}=$ indeks stomata per unit area

Distribusi stomata dihitung menggunakan mikroskop perbesaran $10 \times 10$ dan difoto menggunakan kamera. Selanjutnya foto yang diperoleh dibagi ke dalam 4 kuadran dan dihitung dengan handcounter untuk jumlah stomata dan sel epidermisnya. Setelah distribusi stomata dihitung, selanjutnya luas stomata berdasarkan jari-jari panjang dan jari-jari lebar stomata dihitung dengan rumus:

$$
\text { Luas stomata }=\pi \times a \times b
$$

Keterangan :

$$
\begin{array}{ll}
\pi & =3,14, \\
\mathrm{a} & =\text { Jari-jari panjang stomata } \\
\mathrm{b} & =\text { Jari-jari lebar stomata }
\end{array}
$$

Luas stomata diukur dengan cara mengukur sel penjaga pada stomata dari keenam jenis tanaman, selanjutnya dihitung dengan mikroskop perbesaran 10 $\times 40$ yang telah dikalibrasi terlebih dahulu. Pengkalibrasian mikroskop menggunakan mikrometer objektif dan okuler mengacu kepada Hidayati (2009) dengan rumus

$$
\text { Skala mikrometer okuler : } \frac{\mathrm{A}}{\mathrm{B}} \times 0,01 \mathrm{~mm} \times 1000 \mu \mathrm{m}
$$

Keterangan:

A = Skala pada mikrometer objektif yang berimpitan pada sisi kanan

B = Skala pada mikrometer okuler antara dua garis yang berimpit pada mikrometer objektif

0,01 = Nilai setiap skala pada mikrometer objektif, dalam $\mathrm{mm}$ 
$1000=$ Nilai konversi dari milimeter ke micrometer $(1 \mathrm{~mm}=1000 \mu \mathrm{m})$.

Apabila jenis tanaman, bagian tanaman, dan kombinasi keduanya yang diperoleh menunjukkan hasil yang nyata, maka analisis dilanjutkan dengan uji beda nyata terkecil (LSD) dengan rumus

$$
\mathrm{LSD}=\mathrm{t}_{0.05} \text { dfe } \times \sqrt{\frac{2 \mathrm{MSE}}{\mathrm{r}}}
$$

Keterangan:

$\mathrm{t}_{0.005 \text { dfe }}=$ Nilai distribusi

$t \quad=0,05 \%$

MSE = Rata-rata galat

$r \quad=$ Ulangan (Hanafiah 2010)

Setelah data dianalisis, dilakukan korelasi untuk mengetahui hubungan antara distribusi dan luas stomata dengan menggunakan korelasi Pearson, yaitu dengan metode product-moment mengacu pada Thoifah (2016):

$$
r=\frac{n \Sigma \mathrm{xy}-\left(\sum \mathrm{x}\right)(\Sigma \mathrm{y})}{\sqrt{\left\{( n \Sigma x ^ { 2 } - ( \Sigma ( x ) ^ { 2 } ) \} \left\{\left(n \Sigma y^{2}-\left(\Sigma(y)^{2}\right\}\right.\right.\right.}}
$$

Keterangan:

$r \quad=$ Nilai korelasi

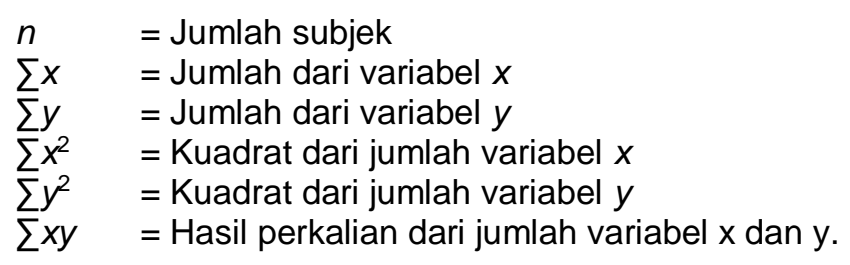

Apabila $r>0$, maka ada hubungan positif antara distribusi stomata dan luas stomata; jika $r<0$, ada hubungan negatif antara distribusi dan luas stomata; jika $r=0$, berarti tidak ada hubungan antara distribusi dan luas stomata; dan jika $r=1$, terdapat hubungan sempurna antara distribusi dan luas stomata. Selanjutnya, kuat atau lemahnya hubungan tersebut diinterpretasikan dengan pedoman korelasi (Sugiyono, 2015).

\section{HASIL DAN PEMBAHASAN}

Berdasarkan analisis faktorial menggunakan SAS (Tabel 1), jenis tanaman berpengaruh nyata pada distribusi stomata. Rata-rata distribusi stomata secara berurutan ialah pucuk merah $50,84 \%$, puring $33,09 \%$, sambang darah, erpah $16,66 \%$, rombusa putih $12,78 \%$, dan bunga kertas $11,69 \%$. Bagian tanaman berpengaruh nyata pada distribusi stomata dengan nilai pada bagian atas $27,81 \%$, tengah $25,52 \%$, dan bawah $23,57 \%$. Sementara itu, kombinasi dari jenis tanaman

\begin{tabular}{|c|c|c|}
\hline Variabel & $\begin{array}{c}\text { Rerata distribusi stomata } \\
(\%)\end{array}$ & Signifikansi \\
\hline Tanaman & & *** \\
\hline Pucuk merah (Syzygium paniculatum Gaertn.) & $50,84^{\mathrm{a}}$ & \\
\hline Puring (Codiaeum variegatum (L.) A. Juss.) & $33,09^{b}$ & \\
\hline Sambang darah (Excoecaria cochinchinensis Lour) & $28,74^{b}$ & \\
\hline Erpah (Aerva sanguinolentaBI.) & $16,66^{c}$ & \\
\hline Rombusa putih (Tabernaemontana divaricata (L.) R. Br. ex Roem. \& Schult.,) & $12,78^{\mathrm{cd}}$ & \\
\hline Bunga kertas (Bougainvillea glabra Choisy) & $11,69^{d}$ & \\
\hline Bagian & & * \\
\hline Atas & $27,81^{\mathrm{a}}$ & \\
\hline Tengah & $25,52^{\mathrm{ab}}$ & \\
\hline Bawah & $23,57^{\mathrm{b}}$ & \\
\hline $\begin{array}{l}\text { Kombinasi tanaman } \\
\text { dan bagian }\end{array}$ & & ns \\
\hline Puring (Codiaeum variegatum (L.) A. Juss.) *atas & 33,06 & \\
\hline Puring (Codiaeum variegatum (L.) A. Juss.) $)^{*}$ tengah & 36,89 & \\
\hline Puring (Codiaeum variegatum (L.) A. Juss.)*bawah & 29,33 & \\
\hline Sambang darah (Excoecaria cochinchinensis Lour)*atas & 30,79 & \\
\hline Sambang darah (Excoecaria cochinchinensis Lour)*tengah & 29,41 & \\
\hline Sambang darah (Excoecaria cochinchinensis Lour)*bawah & 26,03 & \\
\hline Rombusa putih (Tabernaemontana divaricata (L.) R. Br. ex Roem. \& Schult..)*atas & 14,66 & \\
\hline Rombusa putih (Tabernaemontana divaricata (L.) R. Br. ex Roem. \& Schult.,) ${ }^{\star}$ tengah & 13,39 & \\
\hline Rombusa putih (Tabernaemontana divaricata (L.) R. Br. ex Roem. \& Schult.,) ${ }^{*}$ bawah & 10,30 & \\
\hline Erpah (Aerva sanguinolentaBI.)*atas & 18,35 & \\
\hline Erpah (Aerva sanguinolentaBI. $)^{\star}$ tengah & 12,95 & \\
\hline Erpah (Aerva sanguinolentaBI.)*bawah & 18,67 & \\
\hline Bunga kertas (Bougainvillea glabra Choisy)*atas & 13,85 & \\
\hline Bunga kertas(Bougainvillea glabra Choisy)tengah & 11,44 & \\
\hline Bunga kertas(Bougainvillea glabra Choisy)*bawah & 9,77 & \\
\hline Pucuk merah(Bougainvillea glabra Choisy)*atas & 56,16 & \\
\hline Pucuk merah(Bougainvillea glabra Choisy)*tengah & 49,02 & \\
\hline Pucuk merah(Bougainvillea glabra Choisy)*bawah & 47,33 & \\
\hline
\end{tabular}

Tabel 1 Anova RAL faktorial distribusi stomata pada enam jenis tanaman dikotil 
dan bagian tanaman tidak berpengaruh nyata pada distribusi stomata.

Berdasarkan analisis luas stomata (Tabel 2), ratarata luas stomata secara berurutan dari yang tertinggi ialah puring $(373,98 \mu \mathrm{m})$, sambang darah $(169,95 \mu \mathrm{m})$, rombusa putih $(302,51 \mu \mathrm{m})$, erpah $(591,05 \mu \mathrm{m})$, bunga kertas $(340,02 \mu \mathrm{m})$, dan pucuk merah $(133,22 \mu \mathrm{m})$. Bagian tanaman berpengaruh nyata pada luas stomata dengan urutan sebagai berikut: bagian bawah 353,87 $\mu \mathrm{m}$, bagian tengah $328,24 \mu \mathrm{m}$, dan bagian atas 272,71 $\mu \mathrm{m}$.

Setelah perhitungan distribusi dan luas stomata, selanjutnya adalah analisis korelasi Pearson antara distribusi dan luas stomata pada tiga bagian daun tanaman cabang terbawah dari keenam jenis tanaman dikotil. Korelasi antara distribusi dan luas stomata tersebut dapat dibaca menggunakan diagram. Hasil korelasi Pearson dan diagram tebar dapat dilihat pada (Tabel 3). Tiga daun bagian atas, tengah, dan bawah memiliki koefisien korelasi negatif $(-)$ antara distribusi stomata dan luas stomata. Tanaman puring bagian atas memiliki koefisien korelasi $-0,91$, diikuti bagian tengah dan bawah masing-masing $-0,90$ dan $-0,33$, koefisien korelasi pada tanaman sambang darah bagian atas $-0,15$, diikuti bagian tengah dan bawah masing-masing $-0,39$, dan $-0,63$. Adapun tanaman rombusa putih menunjukkan koefisien korelasi untuk bagian atas $-0,95$, diikuti bagian tengah dan bawah masing-masing
$-0,52$ dan $-0,25$; tanaman erpah urutan memiliki koefisien korelasi $-0,99$ untuk bagian atas, dan $-0,97$ baik untuk bagian tengah dan bawah. Akan halnya dengan bunga kertas, koefisien korelasinya berturutturut ialah $-0,96,-0,96$, dan $-0,51$ masing-masing untuk bagian bawah, tengah, dan atas. Pada tanaman pucuk merah ditemukan koefisien korelasi antara distribusi stomata dan luas stomata bagian atas $-0,88$, diikuti oleh bagian tengah dan bagian bawah masingmasing $-0,82$ dan $-0,75$.

Distribusi dan luas stomata diamati pada bagian abaksial (permukaan bawah) dan adaksial (permukaan atas). Keenam tanaman memiliki stomata di permukaan bawah, tetapi spesies erpah, rombusa putih, dan bunga kertas stomata terdapat baik pada permukaan atas maupun bawah.

Berdasarkan perhitungan distribusi stomata pada enam jenis tanaman (Tabel 1), spesies pucuk merah memiliki rata-rata distribusi stomata $50,84 \%$, Puring memiliki rata-rata distribusi stomata $33,09 \%$, Sambang Darah memiliki rata-rata distribusi stomata $28,74 \%$, Erpah memiliki rata-rata distribusi stomata $16,66 \%$, Rombusa Putih memiliki rata-rata distribusi stomata $12,78 \%$ dan Bunga Kertas memiliki rata-rata distribusi stomata $11,69 \%$. Distribusi stomata pada penelitian memiliki jumlah yang berbeda-beda berdasarkan dari enam jenis tanaman dikotil. Nurten \& Ahmet (2014) menyatakan bahwa penyebaran stomata pada

Tabel 2 Hasil Anova RAL faktorial luas stomata pada enam jenis tanaman dikotil

\begin{tabular}{|c|c|c|}
\hline Variabel & $\begin{array}{c}\text { Rerata luas } \\
\text { stomata }\left(\mu \mathrm{m}^{2}\right)\end{array}$ & Signifikasi \\
\hline Tanaman & & *** \\
\hline Erpah (Aerva sanguinolentaBI.) & $591,05^{a}$ & \\
\hline Puring (Codiaeum variegatum (L). A. Juss.) & $374,04^{\mathrm{b}}$ & \\
\hline Bunga kertas (Bougainvillea glabra Choisy) & $340,20^{\mathrm{bc}}$ & \\
\hline Rombusa putih (Tabernaemontana divaricata (L).R. Br. ex Roem. \& Schult.) & $301,18^{\mathrm{c}}$ & \\
\hline Sambang darah (Excoecaria cochinchinensis Lour) & $169,96^{\mathrm{d}}$ & \\
\hline Pucuk merah (Syzygium paniculatum Gaertn.). & $133,23^{\mathrm{d}}$ & \\
\hline Bagian & & *** \\
\hline Atas & $272,71^{\mathrm{b}}$ & \\
\hline Tengah & $328,24^{\mathrm{a}}$ & \\
\hline Bawah & $353,87^{\mathrm{a}}$ & \\
\hline Kombinasi tanaman dan bagian tanaman & & *** \\
\hline Puring (Codiaeum variegatum (L.) A. Juss.) ${ }^{*}$ atas & $213,31^{\text {ef }}$ & \\
\hline Puring (Codiaeum variegatum (L.) A. Juss. $)^{*}$ tengah & $358,65^{c}$ & \\
\hline Puring (Codiaeum variegatum (L.) A. Juss.)*bawah & $550,14^{\mathrm{b}}$ & \\
\hline Sambang darah (Excoecaria cochinchinensis Lour)*atas & $158,81^{\mathrm{g}}$ & \\
\hline Sambang darah (Excoecaria cochinchinensis Lour)*tengah & $164,89^{9}$ & \\
\hline Sambang darah (Excoecaria cochinchinensis Lour)*bawah & $186,16^{\dagger}$ & \\
\hline Rombusa putih (Tabernaemontana divaricate (L.) R. Br. ex Roem. \& Schult., ${ }^{\star}$ atas & $277,72^{\mathrm{e}}$ & \\
\hline Rombusa putih (Tabernaemontana divaricata (L.)R. Br. ex Roem. \& Schult.,)*tengah & $313,71^{d}$ & \\
\hline Rombusa putih (Tabernaemontana divaricata (L.) R. Br. ex Roem. \& Schult.,)*bawah & $312,10^{d}$ & \\
\hline Erpah (Aerva sanguinolentaBI.)*atas & $560,40^{b}$ & \\
\hline Erpah (Aerva sanguinolentaBI.)*tengah & $643,23^{\mathrm{a}}$ & \\
\hline Erpah (Aerva sanguinolentaBI. $)^{*}$ bawah & $569,52^{\mathrm{b}}$ & \\
\hline Bunga kertas (Bougainvillea glabra Choisy)*atas & $315,82^{\text {cd }}$ & \\
\hline Bunga kertas (Bougainvillea glabra Choisy)*tengah & $371,19^{c}$ & \\
\hline Bunga kertas (Bougainvillea glabra Choisy)*bawah & $333,58^{c}$ & \\
\hline Pucuk merah (Syzygium paniculatum Gaertn.)*atas & $110,18^{\mathrm{gh}}$ & \\
\hline Pucuk merah (Syzygium paniculatum Gaertn. $)^{*}$ tengah & $117,77^{\mathrm{h}}$ & \\
\hline Pucuk merah (Syzygium paniculatum Gaertn.)*bawah & $171,72^{\mathrm{fg}}$ & \\
\hline
\end{tabular}


Tabel 3 Korelasi distribusi stomata dan luas stomata pada tiga daun bagian atas, tengah, dan bawah dari enam jenis tanaman dikotil pada cabang

\begin{tabular}{|c|c|c|}
\hline Jenis tanaman & $\begin{array}{l}\text { Bagian } \\
\text { tanaman }\end{array}$ & $\begin{array}{c}\text { Korelasi distribusi stomata } \\
\text { dan luas stomata }\end{array}$ \\
\hline \multirow{3}{*}{ Puring (Codiaeum variegatum (L.) A. Juss.), } & Atas & $-0,91$ \\
\hline & Tengah & $-0,90$ \\
\hline & Bawah & $-0,33$ \\
\hline & Atas & $-0,15$ \\
\hline \multirow[t]{3}{*}{ Sambang darah (Excoecaria cochinchinensis Lour) } & Tengah & $-0,39$ \\
\hline & Bawah & $-0,63$ \\
\hline & Atas & $-0,95$ \\
\hline \multirow{3}{*}{$\begin{array}{l}\text { Rombusa putih (Tabernaemontana divaricata (L.) R. Br. ex Roem. \& } \\
\text { Schult.,). }\end{array}$} & Tengah & $-0,52$ \\
\hline & Bawah & $-0,25$ \\
\hline & Atas & $-0,99$ \\
\hline \multirow[t]{3}{*}{ Erpah (Aerva sanguinolentaBI.), } & Tengah & $-0,97$ \\
\hline & Bawah & $-0,97$ \\
\hline & Atas & $-0,51$ \\
\hline \multirow[t]{3}{*}{ Bunga kertas (Bougainvillea glabra Choisy). } & Tengah & $-0,96$ \\
\hline & Bawah & $-0,96$ \\
\hline & Atas & $-0,88$ \\
\hline \multirow[t]{2}{*}{ Pucuk merah (Syzygium paniculatum Gaertn.), } & Tengah & $-0,82$ \\
\hline & Bawah & $-0,75$ \\
\hline
\end{tabular}

epidermis dipengaruhi oleh variasi dalam spesies dan varietas dalam jenis dan kondisi pertumbuhan. Selain itu, Juairiah (2014) menyebutkan bahwa perbedaan distribusi stomata pada setiap tanaman dapat disebabkan oleh faktor genetik dan fenotipnya serta dipengaruhi oleh faktor lingkungan.

Berdasarkan perhitungan rerata distribusi stomata dari yang tertinggi sampai terendah ialah pada daun bagian atas 27,81\%, bagian tengah 25,52\%, dan bagian bawah $23,57 \%$ (Tabel 1). Temuan ini sejalan dengan penyataan Yudha, Noli \& Idris (2013) nahwa kerapatan stomata pada daun angsana meningkat sampai usia 15 hari dan berkurang pada usia daun 20 dan 25 hari. Hasil Anova RAL faktorial jenis dan bagian tanaman terhadap distribusi stomata berpengaruh nyata, sedangkan kombinasi jenis tanaman dan bagian tanaman tidak menunjukkan pengaruh nyata.

Selanjutnya, analisis mengenai luas stomata berdasarkan panjang dan lebar stomata menggunakan rumus Eberly (2016) yang disajikan pada Tabel 2 menggambarkan bahwa urutan luas stomata terbesar hingga terkecil ialah erpah $(591,05 \mu \mathrm{m})$, puring $(374,04$ $\mu \mathrm{m})$, bunga kertas $(340,20 \mu \mathrm{m})$, rombusa putih $(301,18$ $\mu \mathrm{m})$, sambang darah $(169,96 \mu \mathrm{m})$, dan pucuk merah $(133,23 \mu \mathrm{m})$. Dengan demikian, luas stomata pada keenam jenis tanaman dikotil berbeda-beda. Perbedaan ini diakibatkan oleh genotipe setiap tanaman dan kemampuannya dalam beradaptasi dengan lingkungan. Meriko \& Abizar (2017) menyatakan bahwa luas stomata dipengaruhi oleh dua faktor, yakni genotipe tanaman itu sendiri dan faktor lingkungan yang berasal dari luar tanaman. Selain itu, menurut Juariah (2014), setiap tanaman memiliki respons morfologi dan anatomi berbeda-beda terhadap kondisi lingkungan habitatnya. Salisbury \& Ross (1995) menyatakan keragaman luas stomata dipengaruhi oleh tebal sel penjaga dalam merespons cahaya, $\mathrm{CO}_{2}$, dan konservasi air.
Tanaman pucuk merah memiliki distribusi tertinggi dan luas stomata terendah (Tabel 3). Hal ini memungkinkan tanaman pucuk merah dapat beradaptasi baik dengan perubahan lingkungan. Fitriani, Haryanti, \& Darmanti (2006) menyatakan bahwa stomata pada kentang (Solanum tuberosum L) yang ditanaman pada lokasi berbeda mempunyai jumlah dan luas stomata yang berbeda. Semakin jauh dari Kawah Sikidang, semakin sedikit jumlah stomata dan semakin besar luasnya. Hal ini menunjukkan bahwa tanaman tersebut dapat beradaptasi pada kondisi lingkungan yang berbeda.

Tabel 3 menggambarkan distribusi dan luas stomata tanaman puring bagian atas dan bagian tengah ialah $-0,91$, dan $-0,90$, erpah bagian atas, tengah, dan bawah adalah $-0,99,-0,97$ dan $-0,97$, bunga kertas bagian tengah dan bawah adalah $-0,96$ dan $-0,96$, dan pucuk merah bagian atas dan bagian tengah ialh $-0,88$ dan -0,82. Menurut klasifikasi Sugiyono (2015), kisaran korelasi $-0,99$ dan $-0,82$ tergolong sangat kuat. Sementara untuk sambang darah bagian bawah $(-0,63)$ dan pucuk merah bagian bawah $(-0,75)$, korelasi tergolong kuat. Korelasi distribusi dan luas stomata pada rombusa putih bagian tengah $(-0,52)$ dan bunga kertas bagian atas $(-0,51)$ tergolong sedang, dan puring bagian bawah $(-0,33)$, sambang darah bagian tengah $(-0,39)$ dan rombusa putih bagian bawah $(-0,25)$, tergolong rendah. Korelasi pada tanaman sambang darah bagian atas $(-0,15)$ tergolong sangat rendah. Distribusi yang tinggi menyebabkan luas stomata kecil dan distribusi rendah menyebabkan luas stomata besar. Hakim, Dorly \& Rahayu (2013) menyatakan bahwa distribusi stomata berkaitan dengan luas stomata. Semakin tinggi distribusi stomata luas stomata semakin mengecil, dan semakin rendah distribusi stomata luas stomata semakin membesar. 
Daun tanaman bagian bawah, tengah, dan atas pada cabang terbawah tanaman mempunyai korelasi tergolong sangat kuat. Korelasi pada bagian bawah tanaman menunjukkan distribusi stomata rendah, berbanding terbalik dengan luas stomata. Sebaliknya pada daun tanaman bagian atas, distribusinya tinggi tetapi luas stomata mengecil. Dengan demikian, sekalipun korelasinya menunjukkan sangat tinggi baik pada bagian bawah maupun bagian atas daun, distribusi dan luas stomata berbanding terbalik. Pola korelasi antara distribusi dan luas stomata terjadi pada tanaman puring, rombusa putih, erpah, dan pucuk merah. Al \& Ratnawati (2004) menyatakan bahwa distribusi atau indeks stomata memiliki perbedaan yang nyata antara daun muda dan daun tua; daun muda memiliki distribusi atau indeks stomata yang lebih tinggi dibandingkan dengan daun dewasa dan tua. Akan tetapi, keadaan ini berbeda pada tanaman sambang darah, korelasi pada daun tanaman bagian bawah tergolong kuat $(-0,63)$ dan mengalami penurunan pada daun bagian tengah $(-0,39)$, yang akhirnya korelasi terukur rendah pada daun bagian atas $(-0,15)$. Sementara itu, tanaman bunga kertas korelasi sangat kuat pada daun tanaman bagian bawah dan tengah $(-0,96)$ dan menurun menjadi sedang pada daun bagian atas $(-0,15)$. Perbedaan korelasi antara sambang darah dan bunga kertas dari korelasi empat jenis tanaman sebelumnya perlu dikaji lebih lanjut terkait dengan morfologi dan genetikannya.

Distribusi dan luas stomata dari enam jenis tanaman dikotil memiliki arah hubungan negatif (-). Korelasi negatif menunjukan bahwa hubungan antara distribusi stomata dan luas stomata berbanding terbalik; semakin tinggi distribusi stomata semakin kecil kecil luas stomata, dan sebaliknya. Hal ini sejalan dengan temuan Dewi, Kriswiyanti, dan Sutara (2015), bahwa ukuran stomata (luas stomata) berpengaruh pada distribusi atau indeks stomata. Semakin besar ukuran panjang dan lebar stomata, semakin kecil distribusinya. Rohman dan Hamida (2017) menegaskan bahwa ukuran stomata (luas) memengaruhi distribusi stomata; semakin besar ukuran stomata, semakin rendah nilai distribusi stomata.

\section{KESIMPULAN}

Berdasarkan hasil penelitian jenis tanaman dan bagian tanaman memiliki pengaruh yang signifikan pada distribusi stomata dan luas stomata. Kombinasi jenis tanaman dan bagian tanaman tidak memilik pengaruh yang signifikan pada distribusi stomata akan tetapi memiliki pengaruh yang signifikan pada luas stomata. Korelasi antara distribusi stomata dan luas stomata menggunakan 3 bagian cabang terbawah yaitu bagian atas, tengah dan bawah dari enam jenis tanaman dikotil memiliki korelasi distribusi stomata dan luas stomata berbanding terbalik dengan nilai yang bervariasi. Erpah, Rombusa Putih, Puring dan Pucuk Merah mempunyai korelasi negative yang tergolong sangat kuat antara distribusi stomata dengan luas stomata pada bagian bawah, tengah dan atas tanaman. Tanaman Sambang Darah memiliki korelasi antara distribusi stomata dan luas stomata dengan kategori kuat pada bagian bawah tetapi semakin melemah pada bagian tengah $(r=-0,39)$ dan pada bagian atas $(r=-0,15)$ dengan katerogi sangat rendah. Tanaman Bunga Kertas memiliki korelasi antara distribusi stomata dan luas stomata dengan kategori sangat kuat pada bagian bawah dan tengah $(r=-0,96)$ tetapi pada bagian atas tanaman memiliki ketegori sedang $(r=-0,51)$.

\section{DAFTAR PUSTAKA}

Al S, Ratnawati. 2004. Respon Konduktivitas Stomata dan Laju Transpirasi Rumput Blembem (Ischaemum ciliare, Retzius) di Sekitar Sumber Emisi Gas Kawah Sikidang Dieng. Seminar Nasional FMIPA UNY. Yogyakarta (ID).

David E. 2016. The Area of Intersecting Ellipses. [Internet]. Diunduh 2019 Feb 19. Tersedia pada: https://www.geometrictools.com/Documentation/Ar ealntersectingEllipses.pdf

Dewi NPSR, Eniek K, Pande KS. 2015. Hubungan Kekerabatan 12 Kultivar Brokoli (Brassica oleracea L.) Berdasarkan Karakter Anatomi Stomata. Jurnal Simbiosis III. 1: 291-300.

Fitriani VS, Haryanti, Darmanti S. 2006. Hubungan antara Jarak Tanam dari Kawah Sikidang Dieng dengan Ukuran Sel Penutup dan Jumlah Stomata Daun Tumbuhan Kentang (Solanum tuberosum L). Buletin Anatomi dan Fisologi. 14(2): 47-55.

Hakim AR, Dorly, Sri R. 2013. Keragaman Dan Analisis Kekerabatan Hoya sp. Bertipe Daun Non Sukulen Berdasarkan Karakter Anatomi Daun. Buletin Kebun Raya. 16(1).

Hanafiah KA. 2010. Racangan Percobaan: Teori dan Aplikasi. Jakarta (ID): Raja Grafindo Persada.

Haryanti S. 2010. Jumlah dan Distribusi Stomata Pada Daun Beberapa Spesies Tanaman Dikotil dan Monokotil. Buletin Anatomi dan Fisiologi. XVIII. (2): 21-28.

Hidayati SR. 2009. Analisis Karakteristik Stomata, Kadar Klorofil, Dan Kandungan Logam Berat Pada Daun Pohon Pelindung Jalan Kawasan Lumpur Porong Sidoarjo. Skripsi. Malang (ID): Jurusan Biologi Sisnstek Dan Teknologi Universitas Islam Negeri Malang.

Izza F, Ainun NL. 2015. Karakteristik Stomata Tempuyung (Sonchus arvensis L.) di Universitas Islam Negeri (UIN) Maulana Malik Ibrahim Malang. Seminar Nasional Konservasi dan Pemanfaatan Sumber Daya Alam. Malang (ID): 177-180. 
Juariah L. 2014. Studi Karakter Stomata Beberapa Jenis Tanaman Revegetasi Di Lahan Pasca Penambangan Timah Di Bangka. Widyariset. 17(2): 213-218.

Lawson T, Blatt MR. 2014. Stomatal Size, Speed Stomatal Size, Speed and Responsiveness Impact on Photosynthesis and Water Use Efficiency. Plant Physiology 164: 1556-1570. https://doi.org/ 10.1104/pp.114.237107

Lilianto, Dewi, Marituti .2018. Kadungan Timbal, Debu di Udara dan Daun Tanaman Peneduh di Kota Semarang. Jurnal Life Science. 7(2).

Meriko L, Abizar. 2017. Struktur Stomata Daun Beberapa Tumbuhan Kantong Semar (Nepenthes sp.). Jurnal Ilmu-ilmu Hayati. 16(3). https:// doi.org/10.14203/beritabiologi.v16i3.2398

Nugroho LH, Purnomo, Sumardi I. 2010. Struktur dan Perkembangan Tumbuhan. Jakarta (ID): Swadaya.
Nurten AVCla, Ahmet AYGÜN. 2014. Determination of Stomatal Density and Distribution on Leaves of Turkish Hazelnut (Corylus avellana L.) Cultivars. 20: 454-459. https://doi.org/10.15832/tbd.27845

Rohman F, Ruly H. 2017. Keragaman Karakter Morfologi, Stomata, dan Klorofil Enam Varietas Tembakau Lokal Tulungagung. Buletin Tanaman Tembakau, Serat dan Minyak Industri. 9(1): 15-23. https://doi.org/10.21082/btsm.v9n1.2017.15-22

Salisbury.1995. Fisiologi Tumbuhan Jilid 2. Bandung (ID): ITB.

Setiawan T, Inneke F. S. 2019. Karakteristik Stomata Berdasarkan Estimasi Waktu Dan Perbedaan Intensitas Cahaya Pada Daun Hibiscus tiliaceus Linn. Di Pangandaran Jawa Barat. Jurnal Pro-Life. $6(2)$.

Sugiyono. 2015. Metode Penelitian Kuantitatif, Kualitatif, dan R\&D. Bandung (ID): Alfabeta. 